Article

\title{
Innovations and Other Processes as Identifiers of Contemporary Trends in the Sustainable Development of SMEs: The Case of Emerging Regional Economies
}

\author{
Krzysztof Malik and Anna Jasińska-Biliczak* \\ Department of Economics, Finance and Regional Research, Faculty of Economics and Management, The Opole \\ University of Technology, 45-758 Opole, Poland; k.malik@po.opole.pl \\ * Correspondence: a.jasinska-biliczak@po.opole.pl
}

Received: 1 February 2018; Accepted: 26 April 2018; Published: 27 April 2018

check for updates

\begin{abstract}
Small and medium enterprises (SMEs) are the biggest group of enterprises in the European Union (EU); they are also characteristic of emerging economies. Given this situation, there is a need to provide instruments such as processes that allow them to realize a model of sustainable development. The ability to classify processes and the occurrences within these processes often affects the state of the enterprises. The implementation of innovations, as identified processes, facilities sustainable development for SMEs. The purpose of this article is to find out whether the identification of processes such as innovations has any influence on the competitiveness and sustainable development of SMEs. This study was based on pilot research that examined small and medium enterprises regionally based on the example of an emerging economic region of Poland. The research focused on the identification of the processes and changes happening inside enterprises in terms of understanding the sustainable development concept. The research composition allows the presentation of how SMEs understand the problems analyzed. The study features a new questionnaire, a new definition of sustainable development, and matches those processes identified by the enterprises analyzed with the particular sustainable development dimensions suggested by the authors. In light of the analysis of the literature and the results of this research, the study offers some important contributions in terms of understanding and offering practical meaning to the identification of various processes. The most important finding was that there is a need to raise awareness among entrepreneurs of the fact that innovations are also processes in themselves, which often constitute the sum of other supporting processes occurring within the enterprise. Support in the form of knowledge transfer from experts to SMEs would also be recommended.
\end{abstract}

Keywords: sustainable development; SMEs; competitiveness; enterprise development; innovation; emerging economy

\section{Introduction}

Nowadays, enterprises act in a manner that is difficult to identify with regard not only to the competitive economy, but also the social and natural environment. High standards of living in many countries have been equated with education, computer usage, and the ability to innovate. The key factor for effective change from an emerging economy to a developed economy is a country's strong and continuous economic growth [1]. As an emerging market, a country embarks on an economic reform program that will lead to stronger and more responsible economic performance levels, as well as transparency and efficiency in the capital market. 
It is possible to consider every action or set of actions as being mutually linked or interrelated, where input is converted into output, i.e., the process. On the other hand, a process-based approach applies a system of processes in an organization, along with systematically identifying processes and their interrelations, as well as engaging in proper process management [2], focused on the sustainable development [3] of the enterprise. Economic growth, based on the sustainability development concept, enables emerging economies to gradually close the gap with more developed economies. Activities that develop an economy in transition may include increasing the standards of living, developing a competitive industrial and commercial base, and improving infrastructure. The authors understand sustainable development as being effective for present and future resource management in the economic dimension; for equality and eliminating disproportions in the access to resources available in a given territory in the social dimension; for integrating the building and planning of functional environmental areas and reducing pressure on the environment in the environmental dimension; and for its effective, clear, and participative management in the institutional dimension.

Furthermore, a system is defined as various components forming one structure; the systems approach considers the implications for the functioning of an organization $[4,5]$ of the sum of effects of the fragmentary processes occurring in the organization in time and space. However, this is not a simple sum. The systems approach means using the synergy effect based on the cooperation of various factors. It is not necessarily optimal for the local reality, which may possibly strengthen the final (global) effect [6].

When considering the thus-defined approach to changes taking place in an enterprise, there is no possibility not to mention the eight fundamental rules of the quality management system from which these notions arise. The following rules involve an orientation towards customers, leadership, employee commitment, and a process-based approach to management [7]. Furthermore, in terms of the rules mentioned, a systems approach to management should also be stressed, as well as constant improvement, a posteriori decision-making, and mutually beneficial connections with suppliers $[8,9]$.

With the identification of individual processes as the basic idea [10], the systems approach is understood as the measurement of results in terms of the identification and solution of problems by means of improvements. It is especially important in an emerging market economy (EME), which is defined as an economy with low to middle per capita income [11]. EMEs are also considered to be fast-growing economies. Emerging economies promise a huge potential for growth, but also pose significant political, monetary and social risks. In accordance with the MSCI 2017 Emerging Markets Index [12], the emerging markets in the Americas are Brazil, Chile, Colombia, Mexico, and Peru; in Asia these are China, India, Indonesia, Korea, Malaysia, Pakistan, Philippines, Taiwan, and Thailand; and in Europe, the Middle East and Africa these are the Czech Republic, Egypt, Greece, Hungary, Poland, Qatar, Russia, South Africa, Turkey, and the United Arab Emirates.

Therefore, it is reasonable to analyze Poland, as it is one of the emerging economies of Europe. One of the key characteristic of an EME is an increase in both local and foreign investment (portfolio and direct). A growth in investment in a country often indicates that the country has been able to build confidence in the local economy. Furthermore, an emerging market economy has to consider local political and social factors as it attempts to open up its economy to the world. The people of an emerging market, who are accustomed to being protected from the outside world, can often be distrustful of foreign investment [13].

Strengthening the connection between entrepreneurship in innovation and the dimension of intellectual assets, which depends more on qualified human resources [14,15], can increase the innovation effects at the level of the firm [16]. A transparent scope of responsibilities and liabilities may be established through a focus on such factors as resources, methods and materials, which improves the key operations of the organization [17]. It should be noted that for the effective development of an enterprise, such processes - the effects of which can be objectively verified-are significant, especially for contemporary current enterprises. There are processes that cause innovative changes [18], and they determine their success. According to McGowan [19], creative activity—understood also by its 
competitiveness, with a strong emphasis placed on implementing the idea of the innovative process, as well as being understood as a constant process-begins with noticing an opportunity, yet ends up making a decision regarding whether or not to implement the idea and then access it [20]. The concept of an innovative process, from the point of view of the results produced for the enterprise, is divided into four stages according to Griffin, namely development, applying the developed idea in production, beginning, peak, maturity, and close [21,22].

Finally, it is possible to state that the scientific, technological, organizational, financial, and commercial steps that are connected within the process or processes of an enterprise and that actually take place or are planned, lead to the implementation of innovations [23,24].

\section{Materials, Methods and Hypothesis}

The purpose of this paper is to examine of the impact and essence of processes on the existence and development of enterprises, as well as to present research concerning the process-based approach and the problems associated with process identification in the small and medium-sized enterprise sector. To achieve our results, the method used involved analyzing the literature concerning processes and the process-based approach to enterprise development. Upon completion of this research method [25], having obtained primary data, a questionnaire survey was directed at enterprises in the Opole Province. This allowed the determination of the nature of the existing processes within the enterprises, and the analysis of their location, functioning, and contact with the management systems in the investigated enterprises. Triangulation was then performed, understood as evaluating the same research using two or more methods, with cross-checking analysis. This involved additional verification of the relationships and validity of the data with the aim of deepening the analysis. This was a pilot research project that examined micro-, small- and medium-sized enterprises according to the sector dimension. The research was conducted regionally and identified the processes and changes taking place inside enterprises, while also seeking to understand the "process" concept, which might form the basis for further comparative, international research.

The authors decided to explore the sustainable development of small and medium enterprises sector (SMEs) in the context of emerging regional economies. Thus, this paper includes the following hypothesis:

Hypothesis 1 (H1). SMEs in emerging economies identify internal processes that reveal their understanding of the sustainable development concept.

To study the research hypothesis, a collection of separate data measures were selected. First, a qualitative survey was completed. Second, a focus group interview with a structured questionnaire was used. Finally, there was also an additional open question provided to analyze the enterprises after the analysis of the questionnaire: "How do they understand the definition of sustainable development and how do they identify this in their enterprises?" This provided a better understanding from a subjective point of view. In addition, the standard cross-check analysis was undertaken to verify the relationship and validity of the data. The research process is shown in Figure 1.

\subsection{Characteristics of the Group Analyzed}

In 2015, there were 4,184,469 enterprises in Poland with $99.98 \%$ of these in the SME sector; at the same time there were 40,097 SME enterprises in Opole Province. Enterprises from Opole Province took part in a questionnaire survey conducted anonymously using the questionnaire form. One hundred and fifty enterprises were chosen (randomly) as a sample for the pilot research. The evaluated probe included 93 micro-enterprises, 25 small enterprises, 32 medium-sized enterprises, which were all representative of SMEs in the region. The responses rate was one hundred and fifty enterprises. Among the respondents, four enterprises (micro-enterprises) indicated that they had not encountered the quality management system at all and were also not going to implement changes concerning their 
existing manner of business administration. In spite of this, all of the enterprises answered all the questions in the questionnaire, which related to the cause and analysis of the data presented on the 150 enterprises of Opole Province. The questionnaire is shown in Figure 2.

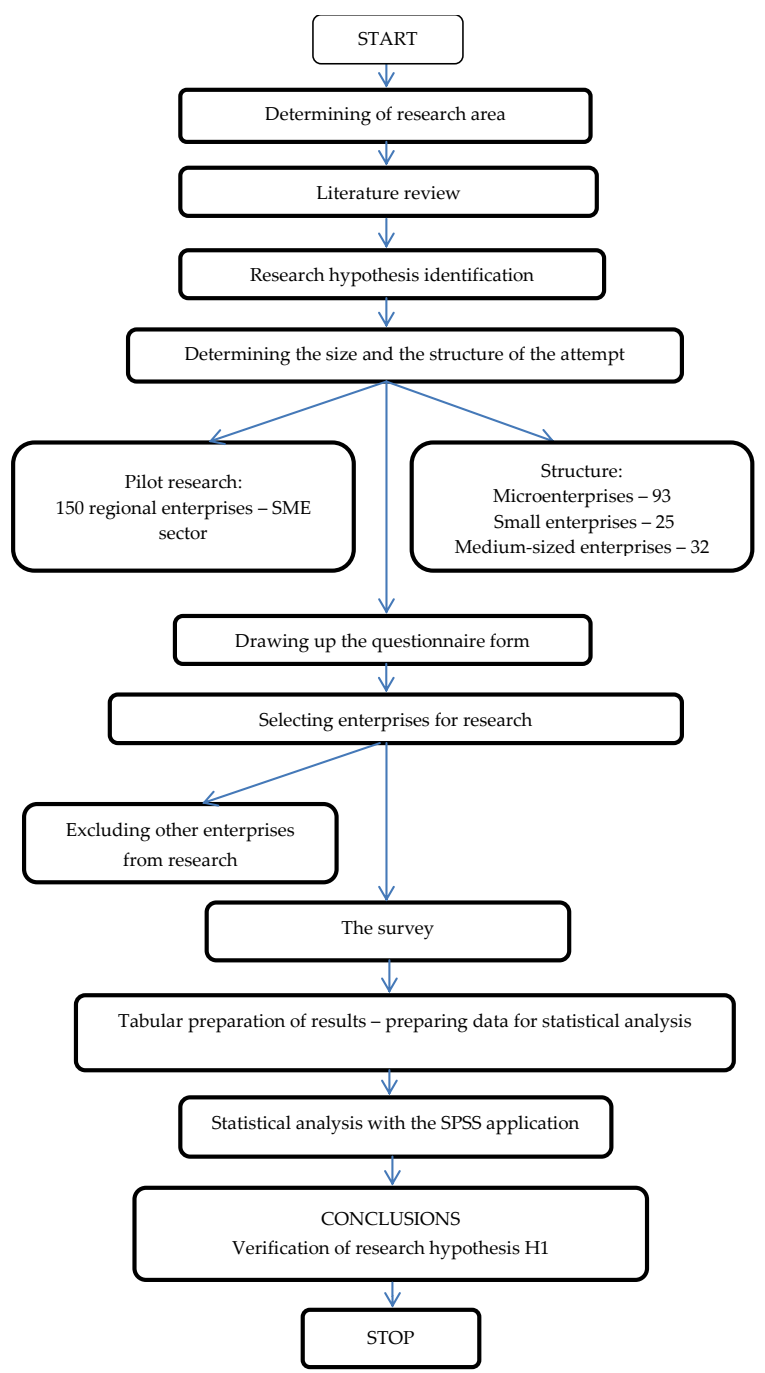

Figure 1. Research process.

\begin{tabular}{|l|l|}
\hline Questions: Innovation and Other Processes & $\begin{array}{l}\text { Q7_An outside organization audited the existing } \\
\text { Total Quality Management }\end{array}$ \\
\hline 1. The company is an enterprise: & Q7_Tax office \\
\hline Q1_micro & Q7_National labour inspectorate \\
\hline Q1_small & Q7_Social insurance institution \\
\hline Q1_middle-sized & Q7_Fire service \\
\hline $\begin{array}{l}\text { 2. Does the enterprise implement any } \\
\text { management system? }\end{array}$ & Q7_Other-Which? ............. \\
\hline $\begin{array}{l}\text { Q2_Yes, implemented, non-certified quality } \\
\text { management system }\end{array}$ & $\begin{array}{l}\text { 8. Is it possible to identify any processes occurring } \\
\text { in the enterprise? (Any number of responses) } \\
\text { If yes, please go to question } 9, \text { if no or you do not } \\
\text { know, please go to question } 10 .\end{array}$ \\
\hline $\begin{array}{l}\text { Q2_Yes, implemented, certified quality } \\
\text { management system }\end{array}$ & Q8_Yes, it is \\
\hline
\end{tabular}

Figure 2. Cont. 


\begin{tabular}{|c|c|}
\hline $\begin{array}{l}\text { Q2_Yes, implemented, non-certified integrated } \\
\text { (ISO 14001) management system }\end{array}$ & Q8_No, it is not \\
\hline $\begin{array}{l}\text { Q2_Yes, implemented, certified integrated (ISO } \\
\text { 14001) management system }\end{array}$ & Q8_I do not know \\
\hline Q2_No & $\begin{array}{l}\text { 9. Which processes is it possible to identify in the } \\
\text { enterprise? (Any number of responses) }\end{array}$ \\
\hline Q2_I do not know & Q9_Cooperation \\
\hline $\begin{array}{l}\text { 3. For which time period has the enterprise had } \\
\text { this system? }\end{array}$ & Q9_Innovation processes \\
\hline Q3_Yes, since last year & Q9_Providing goods \\
\hline Q3_Yes, for 2-3 years & Q9_Accepting goods \\
\hline Q3_Yes, for 4-5 years & Q9_Sales \\
\hline Q3_Yes, for 6 years or longer & Q9_Contact with customers \\
\hline Q3_I do not know & Q9_Sustainable development \\
\hline $\begin{array}{l}\text { 4. Does the implemented management system } \\
\text { existing in the enterprise have any requirements } \\
\text { regarding cooperating enterprise(s)? } \\
\text { If yes, please go to question } 5 \text {, if no or you do } \\
\text { not know, please go to question } 6 \text {. }\end{array}$ & Q9_Flow of information \\
\hline Q4_Yes, it does & $\begin{array}{l}\text { Q9_Implementation of Corporate Social } \\
\text { Responsibility }\end{array}$ \\
\hline Q4_No, it does not & Q9_Sending goods \\
\hline Q4_I do not know & Q9_Flow of documentation \\
\hline $\begin{array}{l}\text { 5. Which requirements are given to cooperating } \\
\text { enterprise(s)? (Any number of responses) }\end{array}$ & Q9_I do not know \\
\hline Q5_Promptness of supplies & $\begin{array}{l}\text { 10. Which levels of cooperation is it possible to } \\
\text { identify in the enterprise? (Any number of } \\
\text { responses) }\end{array}$ \\
\hline $\begin{array}{l}\text { Q5_Adapting their management system to the } \\
\text { enterprise's own standards }\end{array}$ & Q10_International \\
\hline Q5_Service performance with customers & Q10_National \\
\hline Q5_Spare parts for delivered products & Q10_Regional \\
\hline $\begin{array}{l}\text { Q5_Longer guarantee than required under the } \\
\text { binding laws and regulations }\end{array}$ & Q10_Local \\
\hline Q5_I do not know & Q10_I do not know \\
\hline $\begin{array}{l}\text { 6. Does the enterprise have control over the } \\
\text { quality of goods given to the customer(s)? (Any } \\
\text { number of responses) }\end{array}$ & $\begin{array}{l}\text { 11. Which kinds of innovations is it possible to } \\
\text { identify in the enterprise? (Any number of } \\
\text { responses) }\end{array}$ \\
\hline Q6_Studying customer satisfaction on the phone & Q11_Process \\
\hline $\begin{array}{l}\text { Q6_Monitoring the amount of customer } \\
\text { complaints }\end{array}$ & Q11_Product \\
\hline $\begin{array}{l}\text { Q6_Monitoring the reasons for customer } \\
\text { complaints }\end{array}$ & Q11_Marketing \\
\hline $\begin{array}{l}\text { Q6_Checking (randomly) the quality of goods } \\
\text { prepared for delivery to the customer }\end{array}$ & Q11_Organizational \\
\hline Q6_I do not know & Q11_I do not know \\
\hline $\begin{array}{l}\text { 7. Was the enterprise controlled (audited) by } \\
\text { outside organizations within the last three } \\
\text { years? (Any number of responses) }\end{array}$ & Thank you for your participation \\
\hline
\end{tabular}

Figure 2. Survey.

\subsection{Characteristics of the Region and Reason for Its Selection}

The Opole Province was selected for the analysis of the innovative activities of the small and medium-sized enterprise sector. It is a region situated in South West Poland. The Opole Province belongs to the group of small European regions with a population of about one million inhabitants. Amongst the characteristics of the analyzed region is a strong connection with the German economy and the largest international migration of people. It is significant that the multiculturalism of such a 
small region, resulting from historical changes, is visible in its identity. It is also affected by a decreasing number of inhabitants, which contributes to the fact that by 2030 Opole Province will have one of the highest shares of post-working age populations in Poland. It can be stated that this is a region with good living conditions and a high standard of living. Industry is the dominant part of the region's economy, ranked third in the country. An asset of the region is the diversified industry structure, with an medium-level technological industry and a tradition of industrial production. Additionally, the building industry influences the economic growth of the region. Unfortunately, the service sector is still poorly developed. Moreover, the level of innovation in the economy and enterprises, and the Research and Development (R\&D) expenditure is still relatively low. A further positive characteristic is that the Opole region has been identified as the region where European funds are best used in Poland [26].

Therefore, it was reasonable to analyze this Polish region as an example of sustainable development in SMEs in European emerging economies.

\section{Results}

The research conducted concerned the identification of the processes occurring in enterprises based on the example of enterprises from Opole Province. It was possible to formulate conclusions regarding the awareness of entrepreneurs of processes occurring in enterprises owned by themselves and the direction of their future development. It was also possible to show the processes that entrepreneurs met, as well as those they were conscious of (or not), with reference to selecting and controlling the development of enterprises.

One of the first questions following the question about the size of the enterprise concerned the implementation of the management system; the answers that were provided are presented in Tables 1 and 2.

Table 1. Number of enterprises taking part in the research declaring the implementation of a management system based on the ISO 14001 norm as the standard.

\begin{tabular}{ccc}
\hline $\begin{array}{c}\text { Size and Number of Enterprises } \\
\text { Taking Part in Research }\end{array}$ & $\begin{array}{c}\text { Number of Enterprises with an } \\
\text { Implemented and Certified } \\
\text { Quality Management System }\end{array}$ & $\begin{array}{c}\text { Number of Enterprises with an } \\
\text { Implemented but Non-Certified } \\
\text { Quality Management System }\end{array}$ \\
\hline Medium 32 & 17 & 14 \\
Small 25 & 11 & 12 \\
Micro 92 & 4 & 22 \\
\hline
\end{tabular}

Source: Results from our own research.

Table 2. Since when (time period) have the enterprises had the implemented system: number of years/number of enterprises.

\begin{tabular}{ccc}
\hline Medium & Small & Micro \\
\hline 6 and more $/ 7$ & 6 and more $/ 1$ & 6 and more $/ 0$ \\
$4-5 / 4$ & $4-5 / 5$ & $4-5 / 0$ \\
$3-2 / 9$ & $3-2 / 8$ & $3-2 / 16$ \\
1 and less $/ 11$ & 1 and less $/ 9$ & 1 and less $/ 8$ \\
\hline
\end{tabular}

Source: Results from our own research.

Enterprises indicated that they had both implemented and certified systems and non-certified quality management systems. This means that among those entrepreneurs analyzed, there was an awareness of the necessity of implementing systems, identifying the processes occurring in enterprises, as well as the benefits resulting from this for the functioning of the enterprise. Among the answers given by the respondents, it was possible to notice a certain pattern: larger and medium-sized enterprises had systems certified for a longer period of time. However, small and microenterprises had, to a substantial extent, systems lacking certificates, whilst functioning for a shorter period of time. 
The collected data formed proof of a greater awareness among larger enterprises, as well as of the fact that smaller enterprises could only identify processes occurring within them in a less professional manner. It was also concluded that the large structure of larger enterprises could impose the need to gain and implement management systems (including quality).

Further questions allowed data concerning requirements to be obtained by adapting these from the standards of the enterprise of the cooperating entrepreneurs, such as suppliers, sub-suppliers, and subcontractors. One hundred percent of respondents indicated that in terms of the requirements towards cooperating enterprises, the promptness of supplies and compliance with the order or service completion according to its specification, was of importance. Furthermore, $100 \%$ of the enterprises researched indicated that adapting a guarantee to its own standards was one of the requirements given to cooperating enterprises; in addition, $87 \%$ stated that the guarantee should be longer than required under binding laws and regulations; $17 \%$ of respondents required the cooperating enterprises to render services to the customer; only $2 \%$ required spare parts for delivered products. The respondents were unanimous as to the three most important requirements incumbent on cooperating enterprises. Thus, it is possible to state, in the context of the processes and the identification of the processes, especially in terms of the crucial processes occurring in the enterprise, that the identification of such processes was conducted by the enterprises themselves.

Respondents were also asked about the control over the quality of services and/or products delivered to customers. The answers given indicated that $86 \%$ of those researched monitored the quantity of and reasons for customer complaints; $47 \%$ randomly checked (through a quality control department) the quality of goods ready to send to the customer; and $12 \%$ studied customer satisfaction on the phone. This data proved awareness of the importance of reflexive data, along with putting the customer first.

Further questions were connected with conducting an audit by external organizations, as well as indicating the nature of such organizations. Table 3 shows the answers to these questions.

Table 3. Number of enterprises inspected by outside organizations (audit by third parties) along with the type of such organizations.

\begin{tabular}{|c|c|c|c|}
\hline Auditing Organization & $\begin{array}{c}\text { Was the Enterprise } \\
\text { Controlled (Audited) by } \\
\text { Outside Organizations } \\
\text { Within the Three Last } \\
\text { Years? \% of Answers } \\
\text { Yes/No }\end{array}$ & $\begin{array}{c}\% \text { of Enterprises with } \\
\text { External Audits within } \\
\text { the Last Three Years } \\
\text { Yes/No }\end{array}$ & $\begin{array}{c}\text { Comparison: Average in } \\
\text { Poland (\% of Enterprises) } \\
\text { Yes/No }\end{array}$ \\
\hline Sum & $98 \% / 2 \%$ & $100 \%$ & $100 \%$ \\
\hline Outside organization & $5 \% / 95 \%$ & $5 \% / 95 \%$ & $7 \% / 93 \%$ \\
\hline auditing existing TQM & - & $67 \% / 33 \%$ & $72 \% / 28 \%$ \\
\hline Tax Office & - & $14 \% / 86 \%$ & $18 \% / 82 \%$ \\
\hline Social Insurance Institution & - & $2 \% / 98 \%$ & $7 \% / 93 \%$ \\
\hline National Labour Inspectorate & - & $3 \% / 97 \%$ & $4 \% / 96 \%$ \\
\hline Fire Service/Other (which?) & - & $4 \%{ }^{1} / 96 \%$ & $7 \%{ }^{2} / 93 \%$ \\
\hline
\end{tabular}

It should be noted that $98 \%$ of the enterprises analyzed declared that they had been controlled (audited) by outside organizations within the three last years; only $5 \%$ pointed out that the external organization had audited the existing quality management system. Other inspections were made by state agencies entitled to conduct audits as part of the business activity of enterprises.

The final questionnaire dealt with the processes occurring within the enterprise; the processes identified by respondents are presented below in Table 4 . 
Table 4. Processes identified by the researched enterprises.

\begin{tabular}{ccccc}
\hline Process & $\begin{array}{c}\text { \% of Answers }{ }^{\mathbf{1}} \text { in } \\
\text { All Enterprises }\end{array}$ & $\begin{array}{c}\text { \% of Answers in } \\
\text { Microenterprises }\end{array}$ & $\begin{array}{c}\text { \% of Answers in } \\
\text { Small Enterprises }\end{array}$ & $\begin{array}{c}\text { \% of Answers in } \\
\text { Medium-Sized } \\
\text { Enterprises }\end{array}$ \\
\hline Sales & $64 \%$ & $73 \%$ & $63 \%$ & $28 \%$ \\
Contact with customer & $23 \%$ & $42 \%$ & $62 \%$ & $59 \%$ \\
Providing goods & $12 \%$ & $2 \%$ & $11 \%$ & $38 \%$ \\
Accepting goods & $6 \%$ & $3 \%$ & $37 \%$ & $42 \%$ \\
Sending goods & $6 \%$ & $56 \%$ & $43 \%$ & $49 \%$ \\
Flow of information & $74 \%$ & $14 \%$ & $32 \%$ & $67 \%$ \\
Flow of documentation & $51 \%$ & $8 \%$ & $48 \%$ & $72 \%$ \\
Cooperation & $26 \%$ & $9 \%$ & $64 \%$ & $17 \%$ \\
Implemented CSR & $12 \%$ & $3 \%$ & $63 \%$ & $85 \%$ \\
Sustainable development & $79 \%$ & $29 \%$ & $12 \%$ & $27 \%$ \\
Innovation process & $8 \%$ & $4 \%$ & $63 \%$ & $7 \%$ \\
\hline
\end{tabular}

${ }^{1}$ Respondents had multiple-choice answers, for this reason the total number of replies exceeded $100 \%$. Source: Results from our own research.

The processes identified by the enterprises constitute specific markers of perceiving the processed attempts at enterprise development. It is not without significance that enterprises are able to accurately identify the processes occurring within them.

What is interesting is the subjective identification of the processes taking place within companies. It should be pointed out that it was not difficult to specify the existing management system (certified or non-certified) of the companies. However, some of them identified this with sustainable development. This indicates a misunderstanding of the concept of sustainable development by the SME sector. Enterprises indicated the existence of many processes related to their current activities such as sales; contact with customers; providing, accepting, and sending goods; as well as the flow of information and documentation. They also showed the process of cooperation through which they themselves identified international, national, regional, and local cooperation partners. Testing the number of enterprises indicated that the process of cooperation was 100\%; and it was possible, on the basis of the subjective answers of the enterprises, to select the kinds of cooperation occurring in the companies analyzed. These answers are illustrated in Table 5.

Table 5. Kinds of cooperation process identified by the enterprises researched.

\begin{tabular}{ccccc}
\hline $\begin{array}{c}\text { Kind of } \\
\begin{array}{c}\text { Cooperation } \\
\text { Process }\end{array}\end{array}$ & $\begin{array}{c}\text { \% of Answers } \mathbf{1} \\
\text { for All Enterprises }\end{array}$ & $\begin{array}{c}\text { \% of Answers for } \\
\text { Microenterprises }\end{array}$ & $\begin{array}{c}\text { \% of Answers for } \\
\text { Small Enterprises }\end{array}$ & $\begin{array}{c}\text { \% of Answers for } \\
\text { Medium-Sized } \\
\text { Enterprises }\end{array}$ \\
\hline International & $53 \%$ & $15 \%$ & $25 \%$ & $38 \%$ \\
National & $17 \%$ & $31 \%$ & $37 \%$ & $27 \%$ \\
Regional & $16 \%$ & $43 \%$ & $24 \%$ & $21 \%$ \\
Local & $14 \%$ & $11 \%$ & $14 \%$ & $14 \%$ \\
\hline
\end{tabular}

\footnotetext{
${ }^{1}$ Respondents had multiple-choice answers. For this reason, the sum of the replies exceeded 100\%. The data from Table 4 considered cooperation as a 100\% value. Source: Results from our own research.
}

Respondents also regarded implemented corporate social responsibility, sustainable development and innovation as separate processes. In the case of innovation, they divided them into four basic groups (which are presented in Table 6), which may be worth considering as indicators for understanding sustainable development in its economic dimension. 
Table 6. Kinds of innovation identified by the investigated enterprises.

\begin{tabular}{ccccc}
\hline $\begin{array}{c}\text { Kind of Innovation } \\
\text { Occurring in SMEs }\end{array}$ & $\begin{array}{c}\text { \% of Answers } \\
\text { for All Enterprises }\end{array}$ & $\begin{array}{c}\text { \% of Answers for } \\
\text { Microenterprises }\end{array}$ & $\begin{array}{c}\text { \% of Answers for } \\
\text { Small Enterprises }\end{array}$ & $\begin{array}{c}\text { \% of Answers for } \\
\text { Medium-Sized } \\
\text { Enterprises }\end{array}$ \\
\hline Processes & $24 \%$ & $12 \%$ & $18 \%$ & $24 \%$ \\
Product & $19 \%$ & $19 \%$ & $27 \%$ & $37 \%$ \\
Marketing & $21 \%$ & $21 \%$ & $42 \%$ & $17 \%$ \\
Organizational & $36 \%$ & $48 \%$ & $33 \%$ & $22 \%$ \\
\hline
\end{tabular}

${ }^{1}$ Respondents had multiple-choice answers. For this reason, the sum of the replies exceeded $100 \%$. The data from Table 4 were considered as an innovation process and treated as a $100 \%$ value. Source: Results from our own research.

The compilation of those answers was the reason for an additional open question given to the enterprises analyzed: how do they understand the definition of sustainable development and how do they identify it in their enterprises? The definitions proposed were quite similar, and it is probable that the enterprises found this information in available publications (but they were not asked about this) or the Internet, as repeated answers appeared such as:

"Sustainable development is the organizing principle for meeting human development goals while at the same time sustaining the ability of natural systems to provide the natural resources and ecosystem services upon which the economy and society depend" [21].

"Sustainability can be defined as the practice of maintaining processes of productivity indefinitely_natural or human made-by replacing resources used with resources of equal or greater value without degrading or endangering natural biotic systems" which is similar as Lynn et al. [27].

"The desired result is a state of society where living and conditions and resource use continue to meet human needs without undermining the integrity and stability of the natural systems." [28].

"Sustainable development is development that meets the needs of the present without compromising the ability of future generations to meet their own needs. It contains within it two key concepts: the concept of 'needs', in particular, the essential needs of the world's poor, to which overriding priority should be given; and the idea of limitations imposed by the state of technology and social organization on the environment's ability to meet present and future needs." [29].

"Sustainability reporting should be reframed through the lens of four interconnected domains: ecology, economics, politics and culture" [30].

In the answers given in the second part of the additional question, enterprises claimed that they understood internal sustainable development as

"development in all directions" and

"development in all processes appearing in the questionnaire", which suggests it was understood as the processes shown in Table 4;

"we have a certified ISO 1400 system in our enterprise", which seems to suggest that the enterprise equates an environmental management system and sustainable development; or "there is integrated ISO system in our enterprise", which permits the statement that the enterprise equates the integrated quality and environmental management system with sustainable development. 
This confirmed the data within the questionnaire. For other answers, it was possible to use the generalization that sustainable development means the development of the enterprise. However, as actions were treated as coincidental, unconnected and not causing global effects, we are led to the statement that, in the sector of small and medium-sized enterprises analyzed, there was no place for a mature, comprehensive perception of the issue.

In accordance with the concept of sustainable development, it was possible to match the processes signified by the enterprises analyzed with their particular dimensions: selling, providing, accepting and sending goods with the economic dimension, and contacting customers and implementing CSR within the social dimension. The implemented CSR also fulfills the environmental dimension as well as the flow of information and documentation within the institutional dimension. Processes regarded by enterprises as sustainable development were excluded from this part of the analysis as their understanding of the concept was not really connected with its scientific meaning. Processes such as cooperation and innovation seem to fulfill all the dimensions of sustainable development. Therefore, this should receive special consideration and be developed as processes realized by the sustainable development of enterprises.

The cross-check analysis was performed as an additional verification of the relationships and validity of the data, with the aim of deepening the analysis of the findings using statistical methods. The examination of the structure of the answers was conducted using a chi-square test of independence, and the $p$-value was calculated using Monte Carlo simulations [31,32]. Monte Carlo simulations were implemented due to the small sample size (pilot research). According to the established hypothesis, there is a relationship between the management system functioning within the enterprise (certified or non-certified) and the identification of inspections led by outside individuals as third-party audits. There is also a relationship between the management system functioning in the enterprise (with or without a certificate) and with the identification of processes made by the enterprise itself (including innovations) as one of the occurring processes. This may be worth studying to gain an understanding of sustainable development in its institutional dimension. If the significance level $\alpha$ was established as lower than 0.05 , then a $p$-value of less than 0.05 would have led to the confirmation of the given hypothesis.

The following tables (Tables 7 and 8) present the results of the methods applied.

Table 7. Cross-table including the relationship between a certified, implemented management system and its external audit.

\begin{tabular}{ccc}
\hline Value & Audit & Total \\
& $\mathbf{0 . 0 0 / 1 . 0 0}$ & \\
\hline \multirow{2}{*}{ ISO 14001 certified, implemented } & $116 / 0$ & 116 \\
& $26 / 6$ & 32 \\
\hline Total & $142 / 6$ & $148^{1}$
\end{tabular}

${ }^{1}$ Respondents used multiple-choice answers; $\mathrm{x}^{2}=22.669, p=0.00$. Source: Results from our own calculations (SPSS).

Table 8. Cross-table including the relationship between a uncertified, implemented management system and its external audit.

\begin{tabular}{ccc}
\hline Value & $\begin{array}{c}\text { Audit } \\
\text { (.00/1.00 }\end{array}$ & Total \\
& $94 / 6$ & 100 \\
ISO 14001 not certified, implemented & $48 / 0$ & 48 \\
\hline Total & $142 / 6$ & $148^{1}$ \\
\hline
\end{tabular}

${ }^{1}$ Respondents used multiple-choice answers; $\mathrm{x}^{2}=3.002, p=0.083$. Source: Results from our own calculations (SPSS). 
As the $p$-value was higher than 0.05 , it is possible to state that the given hypothesis on the appearance of the relationship was not confirmed by the research. In these conditions, it is possible to state that the functioning of non-certified quality management systems had a smaller effect on the self-awareness of the enterprise than certified the systems. This could be due to a lack of external independent control over the processes occurring in such enterprises; Tables 9 and 10 include a presentation of this further research.

Table 9. Cross-table including the relationship between the certified, implemented management system and all external audits.

\begin{tabular}{ccc}
\hline \multirow{2}{*}{ Value } & $\begin{array}{c}\text { Audit, Tax Office, Social Insurance Institution, } \\
\text { National Labor Inspectorate, Fire Office, Other } \\
\mathbf{0 . 0 0 / 1 . 0 0 / 2 . 0 0 / 3 . 0 0 / 4 . 0 0 / 5 . 0 0}\end{array}$ & Total \\
& $46 / 21 / 1 / 0 / 0 / 0$ & 100 \\
ISO 14001 certified, implemented & $0 / 54 / 19 / 4 / 2 / 1$ & 48 \\
\hline Total & $46 / 75 / 20 / 4 / 2 / 1$ & $148^{1}$ \\
\hline
\end{tabular}

${ }^{1}$ Respondents used multiple-choice answers; $\mathrm{x}^{2}=61.670, p=0.000$. Source: Results from our own calculations (SPSS).

Table 10. Cross-table including the relationship between the uncertified, implemented management system, and all external audits.

\begin{tabular}{ccc}
\hline \multirow{2}{*}{ Value } & $\begin{array}{c}\text { Audit, Tax Office, Social Insurance Institution, } \\
\text { National Labor Inspectorate, Fire Office, Other } \\
\mathbf{0 . 0 0 / 1 . 0 0 / 2 . 0 0 / 3 . 0 0 / 4 . 0 0 / 5 . 0 0}\end{array}$ & Total \\
& $\begin{array}{cc}46 / 33 / 14 / 4 / 2 / 1 \\
0 / 42 / 6 / 0 / 0 / 0\end{array}$ \\
\hline \multirow{2}{*}{ ISO 14001 certified, implemented } & $46 / 75 / 20 / 4 / 2 / 1$ & 100 \\
\hline Total & $148^{1}$ \\
\hline
\end{tabular}

${ }^{1}$ Respondents used multiple-choice answers; $\mathrm{x}^{2}=5.315, p=0.021$. Source: Results of our own calculations (SPSS).

Research was also directed at the processes highlighted by enterprises as processes occurring inside those enterprises. Tables 11 and 12 present this part of the research results.

The values shown demonstrate that the hypothesis was confirmed.

The regional data obtained also corresponded to research on a domestic scale [33], as well as to international research focused on innovations in many forms, not only with regard to the behavior of firms, but also whole societies [34], regional disparities [34-38], the degree of entrepreneurial SME orientation, and sensitivity to changes in the business context [39].

Table 11. The relationship between the uncertified, implemented management system and all other internal processes identified by enterprises.

\begin{tabular}{ccc}
\hline Process $^{\mathbf{1}}$ & $\mathbf{X}^{\mathbf{2}}$ & $p$-Value \\
\hline Sales & 0.823 & 0.364 \\
Contacts with customers & 3.497 & 0.061 \\
Providing goods & 9.219 & 0.002 \\
Flow of information & 4.794 & 0.029 \\
Cooperation & 0.516 & 0.473 \\
Sustainable development & 26.489 & 0.000 \\
Innovation process & 8.012 & 0.005 \\
\hline
\end{tabular}

${ }^{1}$ Respondents used multiple-choice answers. Source: Results from our own calculations (SPSS). 
Table 12. The relationship between the certified, implemented management system and all other internal processes identified by enterprises.

\begin{tabular}{ccc}
\hline Process ${ }^{\mathbf{1}}$ & $\mathbf{X}^{\mathbf{2}}$ & $\boldsymbol{p}$-Value \\
\hline Sales & 3.148 & 0.076 \\
Contacts with customers & 41.946 & 0.000 \\
Providing goods & 69.622 & 0.000 \\
Flow of information & 77.831 & 0.000 \\
Cooperation & 65.453 & 0.000 \\
Sustainable development & 46.745 & 0.000 \\
Innovation process & 60.508 & 0.000 \\
\hline${ }^{1}$ Respondents used multiple-choice answers. Source: Results from our own calculation (SPSS).
\end{tabular}

\section{Discussion}

Small and medium-sized enterprises are "a major engine" of economic growth and socioeconomic development [40]. The process approach is often referred to in the literature as a philosophy that is a cornerstone of the organization of work in a company and the foundation of all business operations and activities [41,42]. The process approach allows organizations to eliminate the biggest disadvantages of a traditional functional approach that cannot be considered to be appropriately flexible to changes in the corporate environment, a variety of procedures, or the excessive replacement of workers $[43,44]$. The objective of the business process can be defined as the development and optimization of running the organization to ensure effective, efficient, and economic reactions to customer requirements [45].

Apart from the identification of processes occurring in the enterprise, it is important to separate the most important ones, namely those which have implications for and an effect on the functioning and survival of the enterprise. Such an approach matches the Pareto rule. The Pareto rule is a tool that is used to determine the significance of the factors (causes) triggering a given problem. According to this principle, it is possible to observe the frequency of the majority of types of events in only small fragments of possible circumstances. The rule states that about $20 \%$ of causes trigger about $80 \%$ of the types of events; hence there are also other expressions of this method such as the "80/20 Method". This relation regards different phenomena, which occur in nature as well as technical and economic systems. The name "Pareto's principle" was first used by Joseph Juran in 1941 for the description of many phenomena in quality research. The authors in [46] states that $80 \%$ of the effects come from $20 \%$ of the effort; in the case of the process-based approach, costs are associated with a given mistake.

It should be noted that, in every organization, it is possible to identify diverse processes at different levels of its operations. Therefore, it is possible to identify:

(1) Primary processes, which have a key importance for the organization and whose effects are transferred directly to the position of the organization;

(2) Support processes, which have the task of supporting primary processes even though they do not have any direct effects on their own; on the contrary, supporting processes often generate costs; and

(3) Management processes, also called general processes, whose task is to assist the efficient functioning of the organization [47-49].

A process-driven company is focused on the outcome of its activities, or the added value for the customer who paid for them; such a company is more flexible and able to respond more quickly to market changes and customer preferences [50]. The aim of process identification is the development and optimization of the daily running of the enterprise in a way that defines the work-related processes; there, each and every process along with its associated input is clearly defined as well as the output or results, and the relevant personal responsibilities are assigned for each and every process or activity while establishing a system for the measurement of the performance and evaluation of every process [51,52]. 
It is possible to state on the basis of this research that enterprises in emerging economies mostly indicate ISO-based managing systems when they are asked about any processes occurring within them. This is characteristic for enterprises in emerging economies and corresponds to EE trends [53,54]. When taking into consideration another criterion of identity the place where the process occurs, it is possible to classify processes as occurring in one or a few cells/departments of the organization. This fact should always be taken into account, that the end (exit) of one process often constitutes the beginning (entry) of another process or processes. Furthermore, within one process, larger processes, or perhaps a few other smaller processes, may occur.

Moreover, areas such as fields of forecasting trends and prospects of pricing as processes, or decision-making under risk and uncertainty have been described as processes in the literature and research into the (fiscal) harmonization of the European Union [55-60].

Today, appropriate technology is often developed using open source principles, which have led to appropriate open-source technology, which has been proposed as a new model enabling innovation for sustainable development [61,62]. This is exemplified by research that ties sustainability to innovation and operational efficiency [63] or environmental impact assessment [64]. SMEs also emphasize care for future generations [65] and social capital [66]. Therefore, it seems possible to raise their innovation level as a process through the realization of the sustainable development concept. Innovative processes that occur within enterprises are also known to be successful innovation management models [67]. Research reveals that the innovation process is still not sufficiently developed in the EE small and medium-sized enterprises sector. The analysed sector should be supported in terms of innovation development. By including sustainable development concepts as the realization of a process-based approach, it is worth pointing out that the social capital of enterprises is the missing ingredient in successful practice that economics cannot explain [68]. SMEs identify sustainable development as one of the processes occurring within them. Sustainable development should be treated as the aim of enterprise development, not only as a process. Small and medium-sized enterprises require educational support and coaching aimed at a proper understanding of the sustainable development concept and the benefits of its implementation.

Emerging economy enterprises are embracing the sustainability challenge in their products and processes, through their measurement and reporting, and in how they see themselves and their future. Emerging economies will also be central players in shaping tomorrow's enterprise development standards. They are also challenging many of the sustainability standards established in economic practice.

\section{Conclusions}

The identification of processes is of key importance for the efficiency and direction of the development of effective enterprises. The process-based approach in business administration undoubtedly requires additional work from the enterprise; however, this is developed into measurable end results connected with customer satisfaction as well as with the reduction of the costs related to the malfunctions taking place in the enterprise.

Regarding small and medium-sized enterprises, the research arrived at the following conclusions, making it possible to state that the enterprises analyzed had relatively small numbers of implemented and certified quality management systems, and medium-sized enterprises often kept their own standards regarding the quality of management systems. Therefore, they regarded this system as an instrument of correct functioning.

On the other hand, small enterprises mostly identified internal processes and had effective quality management systems according to their own standards; however, they did not verify the correctness of either the data obtained in this way or the indicators. The research allowed us to point out that enterprises that did not have certified quality management systems did not connect the monitoring conducted by outside organizations such as the Revenue Office or the National Labor Inspectorate, with a system of third party auditing; furthermore, for the smaller enterprises, the identification of 
processes made independently was less correct than those conducted by the enterprises themselves. In addition, smaller enterprises believed that international cooperation was an essential process; this is a recent, yet indispensable trend in the search for sales markets and opening the SME sector to change. Nowadays, what is important for economic theory, especially for the sustainable development concept used in practice, is an enterprise's system of social responsibility, which is more often perceived as a separate process. The identification of social responsibility in enterprises as a process inside these enterprises proves the significance of their social and environmental awareness, and, at the same time, their effective realization of the sustainable development concept. As the research demonstrated, it is possible to conclude that enterprises identify their own development as a process, rather than as a marker of the effectiveness of the processes occurring inside the enterprise, and, in spite of this fact, $79 \%$ of respondents regarded the changes occurring in the enterprise as the process, although only $8 \%$ identified the change that applies to innovative solutions. The data indicated the need to raise awareness among entrepreneurs of innovations as a process that often constitutes the sum of other supporting processes occurring in the enterprise.

On the basis of the case study analyzed, the authors see misunderstandings in the way SMEs in emerging economies use and understand the concept of sustainable development, as the enterprises in the sector analyzed might have used a scientific source to provide a definition of sustainable. In our analysis, we asked for the entrepreneurs' own, subjective understanding of that concept, where they demonstrated a basic misunderstanding. The SMEs in this emerging economy equated sustainable development with quality management systems, integrated quality and environmental management systems, or simply regarded any development as sustainable.

The final conclusion regards the recommendation for the support of micro- and small-sized enterprises in the form of knowledge transfer from experts. This would be worthwhile by helping them to establish and organize their own sustainable development strategies, based on expert experience and knowledge. Certainly, such solutions would contribute to the regularity of the actions of enterprises, which is typical for the identification of processes occurring in an enterprise; these involve processes that directly contribute to its development (such as innovative processes) and apply enterprise resources more effectively. Furthermore, the enterprises should apply special consideration to the identification of both processes, cooperation and innovation, to fulfil all the dimensions of sustainable development. Regional authorities with such knowledge at their disposal should add the development of actions supporting the creation of such processes in enterprises to regional strategies.

Moreover, the identification of processes as well as establishing sustainable development strategies for professional enterprises may bring benefits connected with early detection, at the same time providing the possibility of preventing potential shortcomings and mistakes. Sustainable projects and technologies should be a motor for regional challenges and drive regional markets.

Using the sustainable development approach for the development of enterprises would undoubtedly result in benefits contributing to the competitive success of the enterprise. As the presented research was conducted as a pilot study, based on the example of an emerging economy region, this issue requires further study. Thus we are planning to conduct a comparative study and to include other European countries that feature emerging economies.

Author Contributions: K.M. and A.J.-B. designed the article and research; K.M. and A.J.-B. conducted the desk research and analyzed the data; K.M. and A.J.-B. wrote the paper.

Conflicts of Interest: The authors declare no conflict of interest.

\section{References}

1. Roztocki, N.; Weistroffer, H.R. Information and Communication Technology in Transition Economies: An Assessment of Research Trends. Inf. Technol. Dev. 2015, 21, 330-336. [CrossRef]

2. Rogers, E.M. Communication of Innovations: A Cross-Cultural Approach; Free Press: New York, NY, USA; London, UK, 2003; p. 36. 
3. Junquera, B.; del Brio, J.A. Factores de éxito en la implantación de la ISO 14001: Un análisis empírico para las empresas industriales españolas. Revista Asturiana de Economia 2002, 24, 131-151.

4. Mansfield, E. Principles of Macroeconomics, 7th ed.; W.W. Norton \& Co. Ltd.: New York, NY, USA, 1989; p. 473, ISBN 978-0-393-96173-7.

5. Davila, T.; Epstein, M.J.; Shelton, R. Making Innovation Work—How to Manage It, Measure It, and Profit from It; Wharton School Publishing: Upper Saddle River, NJ, USA, 2006; pp. 67-123, ISBN 9780133093391.

6. Junquera, B.; Fernandez, E. Lights E Shadows of Political Leadership (Political Leaders and Their Assesment); Nova Publisher: Hauppauge, NY, USA, 2011; pp. 27-34, ISBN 978-1-61728-760-2.

7. Dervitsiotis, K.N. A framework for the assessment of an organisation's innovation excellence. Total Qual. Manag. Bus. Excell. 2010, 21, 903-918. [CrossRef]

8. Rosen, M.A.; Dincer, I.; Kanoglu, M. Role of Exergy in Increasing Efficiency and Sustainability and Reducing Environmental Impact. Energy Policy 2008, 36, 128-137. [CrossRef]

9. OECD and Eurostat. Oslo Manual: Guidelines for Collecting and Interpreting Innovations Data; OECD and Eurostat: Paris, France, 2005; pp. 46-47.

10. Tinnesand, B. Towards a General Theory of Innovation; University of Wisconsin: Madison, WI, USA, 1973; p. 258.

11. Yeyati, E.L.; Wiliams, T. Emerging economies in the 2000s: Real decoupling and financial recoupling. J. Int. Money Financ. 2012, 31, 2102-2126. [CrossRef]

12. MSCI 2017 Emerging Markets Index. Available online: https://www.msci.com/market-classification (accessed on 24 April 2018.).

13. Heakal, R. What is Emerging Market Economy? 2017. Available online: https://www.investopedia.com/ articles/03/073003.asp30.11.2017 (accessed on 1 December 2017).

14. Malik, K. Smart Specialisation and Key Enabling Technologies in the New Regional Development Policy. In Local and Regional Economy in Theory and Practice, 1st ed.; Markowska, M., Głuszczyk, M., Bal-Domańska, B., Eds.; Wroclaw University of Economics: Wrocław, Poland, 2014; Volume 334, pp. 118-127.

15. Szewczyk, M. Research into the Regional Potential of Innovations on the Example of the Opolskie Voivodeship. In Effective Transfer of Knowledge from Science to Industry in the Opolskie Voivodeship. Requirements for Effective Cooperation, 1st ed.; Malik, K., Dymek, Ł., Eds.; Wydawnictwo Difin: Warszawa, Poland, 2015; pp. 102-109, ISBN 978-83-7930-785-2.

16. Szabo, Z.K.; Šoltés, M.; Herman, E. Innovative Capacity \& Performance of Transition Economies: Comparative Study at the Level of Enterprises. E+M Ekon. Manag. 2013, 16, 52-68.

17. Afuah, A. Strategic Innovation: New Game Strategies for Competitive Advantage, 1st ed.; Taylor \& Francis Inc.: Abingdon, UK, 2009; p. 92, ISBN 978-0415997812.

18. Jasińska-Biliczak, A. Instrumenty Wspierające Sektor Małych i Średnich Przedsiębiorstw na Poziomie Lokalnym-Przykład Powiatu Nyskiego, 1st ed.; Brol, A., Sztando, A., Raszkowski, A., Eds.; Wroclaw University of Economics/Prace Naukowe Uniwersytetu Ekonomicznego we Wrocławiu: Wrocław, Poland, 2014; Volume 332, pp. 54-63, ISBN 978-83-7695-488-2.

19. McGowan, P. Innowacje i przedsiębiorczość wewnętrzna. In Praktyka Kierowania, 1st ed.; Stewart, D.M., Ed.; PWE: Warszawa, Poland, 1994; pp. 281-283.

20. Jasińska-Biliczak, A.; Sitkowska, R. Influence of small and medium enterprises sector at the change of innovation potential of Polish regions. Grant J. 2014, 3, 57-61.

21. Griffin, R.W. Fundamentals of Management, 7th ed.; South-Western CENGAGE Learning: Mason, OH, USA, 2013; pp. 73-90, ISBN 978-1133627494.

22. Taddeo, R.; Simboli, A.; Ioppolo, G.; Morgante, A. Industrial symbiosis, networking and innovation: The potential role of innovation poles. Sustainability 2017, 9, 169. [CrossRef]

23. Sipikal, M.; Pisar, P.; Uramova, M. Support of innovation at regional level. E+M Ekonomie a Management 2010, 13, 74-85.

24. Yun, J.J.; Lee, D.; Ahn, H.; Park, K.; Yigitcanlar, T. Not Deep Learning but Autonomous Learning of Open Innovation for Sustainable Artificial Intelligence. Sustainability 2016, 8, 797. [CrossRef]

25. MSCI. Emerging Markets Index. 2017. Available online: https://www.msci.com/market-classification (accessed on 30 November 2017).

26. Eparvier, P. Methods of Evolutionism and Rivalry with Neoclassical Analysis. The Example of the National System of Innovation Concept. J. Econom. Methodol. 2005, 12, 563-578. [CrossRef] 
27. EU Funds in Central and Eastern Rurope. August 2016. Available online: https:/ /assets.kpmg.com/content/ $\mathrm{dam} / \mathrm{kpmg} / \mathrm{pdf} / 2016 / 06 /$ EU-Funds-in-Central-and-Eastern-Europe.pdf.2 (accessed on 9 November 2017).

28. Kahle, L.R.; Gurel-Atay, E. (Eds.) Communicating Sustainability for the Green Economy, 1st ed.; M.E. Sharpe: New York, NY, USA, 2014; pp. 49-114, 167-209, ISBN 978-0-7656-3680-5.

29. United Nations. Report of the World Commission on Environment and Development. Brundtland Commission; United Nations: Oslo, Norway, 20 March 1987; p. 4.

30. Mansfield, E. Statistics for Business E Economics. Methods and Applications, 5th ed.; Norton \& Company: New York, NY, USA; London, UK, 1987; pp. 47-63, ISBN 978-0393964608.

31. Smith, P.W.; Forster, J.J.; McDonald, J.W. Monte Carlo exact tests for square contingency tables. J. R. Stat. Soc. Ser. A 1996, 159, 309-321. [CrossRef]

32. GUS. Innovative Actions of the Enterprises in Years 2013-2015. Information and Statistics; GUS: Warsaw, Poland, 2016; pp. 112-136.

33. Hawksworth, J.; Tiwari, A. The World in 2050. The Accelerating Shift of Global Economic Power: Challenges and Opportunities; PwC: London, UK, 2011; pp. 30-32, ISBN 150128-085441-DC-OS.

34. Vokoun, M. Innovation behaviour of firms in small open economy: The case of the Czech manufacturing industry. EMPIRICA 2016, 43, 111-139. [CrossRef]

35. Malik, K. The Effectiveness and Efficiency of Regional Development Policy. In Research and Perspectives-Herausforderungen, Forschung und Perspektiven, European Research and Working Group, 1st ed.; Hofbauer, G., Hauke, H., Eds.; Uni-Edition GmbH: Berlin, Germany, 2012; pp. 287-300, ISBN 978-3-942171-86-1.

36. Foray, D.; Gault, F. Measurement of Knowledge Management Practices. Measur. Knowl. Manag. Bus. Sector: First Steps 2003, 7, 292-311.

37. Heimpold, G. Neue Orientungen für die deutsche Raumentwicklungpolitik?-Bericht über einem Workshop im IWH im Juni 2005. Wirtsch. Wandel 2005, 2, 34-36.

38. Hobcraft, P. Moving Towards a Distributed Innovation Model. 2011. Available online: http:/ /www.businessstrategy-innovation.com (accessed on 1 December 2017).

39. Arend, R.J. Ethics-focused dynamic capabilities: A small business perspective. Small Bus. Econ. 2013, 41, 1-24. [CrossRef]

40. Henderson, J.; Weiler, S. Entrepreneurs and job growth: Probing the boundaries of time and space. Econ. Dev. Q. 2010, 24, 23-32. [CrossRef]

41. Llewellyn, N.; Armistead, C. Business process management: Exploring social capital within processes. Int. J. Serv. Ind. Manag. 2000, 11, 225-243. [CrossRef]

42. Lundvall, B.Å. National Systems of Innovation: Toward a Theory of Innovation and Interactive Learning, 2nd ed.; Anthem: London, UK, 2010; pp. 118-185, ISBN 0521689538.

43. Ratanawaraha, A.; Polenske, K.R. Measuring the Geography of Innovation. In The Economic Geography of Innovation; Polenske, K.R., Ed.; University Press: Cambridge, UK, 2007; p. 274.

44. European Union. Report on the 2012 ERAC Mutual Learning Seminar on Research and Innovation Policies; European Union: Brussels, Belgium, 24 January 2012.

45. Murdock, K.A. The Effect of Public Policy for Entrepreneurship and Innovation in EU's Managed and Entrepreneurial Economies; Universitat Autonoma de Barcelona: Barcelona, Spain, 2010; pp. 127-134, ISBN 978-951-38-8317-1.

46. Juran, J.M. Juran on Quality by Design; Free Press: New York, NY, USA, 1992; pp. 68-71.

47. Armisted, C.; Rowland, P. Managing Business Processes; Wiley and Sons: Chichester, UK, 1996; p. 35.

48. Miller, J.G.; Vollman, T.E. The Hidden Factory. Harv. Bus. Rev. 1985, 63, 142-150.

49. Porter, M. Competitive Advantage; Free Press: New York, NY, USA, 1985; p. 23.

50. Von Hippel, E. Democratizing Innovation; The MIT Press: Cambridge, MA, USA, 2005; p. 142, ISBN 9780262002745.

51. Ashford, N.A.; Hall, R.P. Technology, Globalization and Sustainable Development: Transforming the Industrial State; Yale University Press: New Haven, CT, USA, 2011; 720p.

52. Younis, A.I.; Nor'Aini, Y. Innovation Creation and Innovation Adoption: A Proposed Matrix Towards a better Understanding. Int. J. Organ. Innov. 2010, 3, 303-325.

53. Ioppolo, G.; Cucurachi, S.; Salomone, R.; Saija, G.; Shi, L. Sustainable Local Development and Environmental Governance: A Strategic Planning Experience. Sustainability 2016, 8, 180. [CrossRef]

54. OECD. Special Focus: Inequality in Emerging Economies (EEs); OECD: Paris, France, 2011. 
55. European Commission. Communication from the Commission, EUROPE 2020, A Strategy for Smart, Sustainable and Inclusive Growth; European Commission: Brussel, Belgium, 2010.

56. Liao, S.H.; Fei, W.C.; Chen, C.C. Knowledge Sharing, Absorptive Capacity, and Innovation Capability: An Empirical Study of Taiwan's Knowledge-intensive Industries. J. Inf. Sci. 2007, 33, 340-359. [CrossRef]

57. Elert, N.; Henrekson, M.; Stenkula, M. Innovation, Entrepreneurship and the Complementary Skill Structure. In Institutional Reform for Innovation and Entrepreneurship; Springer: Cham, Switzerland, 2017; pp. 9-23, ISBN 978-3-319-55091-6.

58. OECD. OECD Innovation Strategy 2015; An Agenda for Policy Action. In Proceedings of the Meeting of the OECD Council at Ministerial Level, Paris, France, 3-4 June 2015.

59. Gangeswari, T.; Roziah, M.R.; Bahaman, A.S.; Maimunah, I. Knowledge sharing is knowledge transfer: A misconception in the literature. J. Knowl. Manag. 2016, 20, 108-122. [CrossRef]

60. Johnson, M.P. Sustainability Management and Small and Medium Sized Enterprises: Managers' Awareness and Implementation of Innovative Tools. Corp. Soc. Responsib. Environ. Manag. 2015, 2, 271-285. [CrossRef]

61. Pearce, J.; Albritton, S.; Grant, G.; Steed, G.; Zelenika, I. A new model for enabling innovation in appropriate technology for sustainable development. Sustain. Sci. Pract. Policy 2012, 8, 42-53. [CrossRef]

62. Zelenika, I.; Pearce, J.M. Innovation Through Collaboration: Scaling up Technological Solutions for Sustainable Development. Environ. Dev. Sustain. 2012, 16, 1299-1316. [CrossRef]

63. Starik, D.; Marcus, A.A. Introduction to the special research forum on the management of organizations in the natural environment. Acad. Manag. J. 2000, 43, 539-546. [CrossRef]

64. Bruhn-Tysk, S.; Eklund, M. Environmental impact assessment e a tool for sustainable development? A case study of biofuelled energy plants in Sweden. Environ. Impact Assess. Rev. 2002, 22, 129-144. [CrossRef]

65. Le Breton-Miller, I.; Miller, D. Why Do Some Family Businesses Out-Compete? Governance, Long-Term Orientations and Sustainable Capability. Entrep. Theory Pract. 2016, 6, 731-746. [CrossRef]

66. Habbershon, T.G.; Williams, M.; MacMillian, I.C. A Unified Systems Perspective of Family Firm Performance. J. Bus. Ventur. 2003, 4, 451-465. [CrossRef]

67. Tidd, J.; Bessant, J.; Pavitt, K. Managing Innovation, 3rd ed.; Wiley: New York, NY, USA, 2005; pp. 52-59, ISBN 978-0470093269.

68. Dyllick, T.; Hockerts, K. Beyond the business case for corporate sustainability. Bus. Strateg. Environ. 2002, 11, 130-141. [CrossRef] 